\title{
The Efforts of Independent Lepers Association in Developing Life Long Education among the Lepers in District of Soreang, Parepare, Indonesia
}

\author{
Nur Ida \\ Jln. Geger Kalong Girang 14, Bandung 40154, West Java, Indonesia \\ nuridapls@yahoo.co.id
}

\begin{abstract}
Parepare is a city located in South Sulawesi province, Indonesia. By having dense population, cultural diversities, and special characteristics in its communities, turn Parepare to have various social problems including; unemployment, crime, poor education, as well as cases of infectious diseases that cause sufferers to experience social dysfunctions for instance, leprosy. Leprosy leads to social problem such as stigma and discrimination in the community. The stigma of the disease which is identical with poor people is a big social problem like the difficulty to be hired and get a job. The research was conducted in Lauleng area in district of Soreang, Parepare. The reason for selecting the area was based on its characteristic as an endemic leprosy area. This was a qualitative research. The results of the research described that Lepers Association in Life Long Education organization built trust by improving the trust among members, members and other people, as well as their partners. The organization built a social relation by establishing trust with the public through information media, as well as creating a norm by balancing the rights and obligations of all members. Meanwhile, the obstacles faced were lack of human resources support due to low education, lack of openness among its members, as well as lack of members' awareness of the association. The conclusion of this research was that Independent Lepers Association in Life Long Education among Lepers in district of Soreang as the organization process of empowering people who were experienced and were suffering leprosy was conducted and organized by a social organization in order to gain a proper living for themselves or others.
\end{abstract}

Keywords: Leprosy, Lepers, Life Long Education

\section{INTRODUCTION}

Parepare is a city located in Province of South Sulawesi. It has dense of population with various cultural diversities and different society characters. The city also has several social problems that haunted the residents for instance; unemployment, high criminality, low education, and some transmitted diseases which cause the sufferer social dysfunction like leprosy.

Leprosy has become a complex and complicated disease which bond to humanity. The problem faced by its sufferer are not only the medical problem but also psychological problem. Medically, the disease causes disability. Moreover, it also left permanent scars which make other people keep their distance to the lepers. These problems can cause the lepers to have social malfunction, disability to be employed, and lead them to do crime or other social disturbance among the society. [1]

Based on the data from Ministry of Health, there were 14 provinces which have high percentage on Leprosy, these are Aceh, East Jawa, North Sulawesi, Southeast Sulawesi, West Papua, Gorontalo, West Sulawesi and South Sulawesi. While in getting the information about the leprosy in all city/regency in Indonesia, it need very long time to be conducted. In 2015, the government tried to eliminate some leprosy cases in province of Banten and then in 2016 the elimination was conducted in province of Aceh and South Sulawesi.

In addition, according to Ministry of Health, Indonesia placed the third place as the highest leprosy in 2012 with new cases reached 18.994 sufferers. While the first place was India with 134.752 cases. In the second place was Brazil with 33.303 cases. In the fourth place was Bangladesh with 3.688 cases and fifth place was Congo with 3.607 cases. "Meanwhile in 2014 there were 8.526 cases and in 2013 there were 16.825 cases. It had not being counted from all cases". [2]

The Minister of Health also added that even though Indonesia had reached national level elimination, because the prevalence was $<1$ per 10.000 resident in 2000, but until now there were still 14 provinces with high percentage of leprosy. Four of it were East Jawa, West Jawa, Central Jawa, and South Sulawesi reported more than 1000 cases for each year. By considering the massive effect of leprosy disability, WHO declared target of Global Strategy for Further Reducing the Disease Burden due to Leprosy in 2011-2015 by decreasing $35 \%$ of the cases in phase 2 by the end of 2015 from data of 2010. Also to establish the efforts of independent association in developing lifelong education among lepers community.

The leprosy case is almost found widespeadly in all part of Indonesia. It's usually transmitted to poor people who live in frontier area. Some endemic main lands of leprosy were Jawa, Sulawesi, Papua, and Maluku. According to one of online media, $30 \%$ of lepers were dominated by people in South Sulawesi, the spread covered 12 cities which had1per 10.000 residents. Data from Health Department of South Sulawesi informed that there were 5000-6000 new cases found per year. 
In 2010 there were 6.040 cases and 2012 were 3.270 cases. [3], the high percentage of Leprosy was also found in Parepare. In September from 2010 - 2012, there were 370 cases found among 567.759 residents checked by the Health Department. While other suspect of leprosy symptom reached 1.798 residents. The transmition of the endemic leprosy in Parepare was in Lauleng, District of Soreang. By considering the situation, some leper survivors decided to maintain an organized association which care to humanity and social living of others lepers, named Independent Lepers Association assisted by alumni of Pendidikan Luar Sekolah (PLS). The association has a futuristic vision which is aiming to exclude the sufferers of leprosy to be free from negative stigma and discrimination in order to gain proper life condition. While the mission are to advocate and build the concern to the lepers and those who has suffer from it, establish the equality in each sector of economy, social, politic, spiritual, education, and health service, and the last is to increase the human resources quality by providing a well-education program to those who suffer leprosy. [4]

Lifelong education became an enormous effort in maintaining social wealthy in macro sector or what being commonly mentioned as community intervention which referred to community development. Macro intervention was a direct intervention which designed in order to deliver an improvement structurally in the level of organization and community. [5]

The researcher was interested in conducting a research under a tittle The Efforts of Independent Lepers Association in Developing Life Long Education among The Lepers in District of Soreang, Parepare. This research focused on examining the social dimension from people who had suffered leprosy, which related to how they develop and maintain lifelong education among the community especially those who had suffer it in district of Soreang, Parepare. By knowing the value of life long education among the lepers community, it could be developed and invested as sources in organizing and developing the community.

\section{A. Problem statements}

- How to build and strengthen a relation, trust, and norms both inside and outside the community?

- How the values of lifelong education affect the community in order to increase the welfare of people who have suffer leprosy?

- How to reach an independent point and welfare of the lepers and people who had suffer it by education and training?

\section{B. Objectives}

- To build and strengthen a relation, trust, and norms both inside and outside the community.

- To know the values of lifelong education affect the community in order to increase the welfare of people who have suffer leprosy.
- To know the independent point and welfare of the lepers and people who had suffer it.

\section{METHODS}

This research was basically focused on understanding contextually and getting a clear perspective of a research entitled The Efforts of Independent Lepers Association in Developing Life Long Education among The Lepers in District of Soreang, Parepare. This research employed descriptive study. It was conducted at district of Soreang Parepare by using purposive sampling technique in deciding the informant. The data were collected through direct observation of active participants and in-depth interview, document study like literatures, official documents, pictures, and so on. The data analysis were data collection, data transcription, coding, data grouping, hypothesis, triangulation and conclusion. To test the reliability, the researcher used data source triangulation and theory.

\section{RESULT AND DISCUSSION}

Social and cultural conditions in Soreang are similar with others that still have a strong belief. [6], against the traditions and customs from generation to generation, as is customary rejection of people suffering from leprosy and rejection by the community towards lepers who's classified as extreme. According to one local village community leader, people who suffer leprosy are categorized as despicable person, they got the curse in the form of contagious and deadly disease. Therefore, people suffering from leprosy are excluded from the community. The high stigma and discrimination for the lepers have made some of them form a community, the community which contains people who have had leprosy and those who are still affected by leprosy.

This community becomes a social organization formed by large organizations that deal with leprosy named Independent Lepers Association with a range of Trustees, the Board, and the members are people with leprosy and people who are suffering from leprosy both local and central. This organizational activities assisted by national and international institutions that deal with health problems, especially problems of leprosy, and donors focused on leprosy. Association of Independent Leprosy Parepare was established on March 23, 2008, which begins by establishing Personal Care Group (KPD), while the KPD is formed from Parepare City Health Department as a place people affected by leprosy to perform maintenance on the suffered disease. Independent Lepers Association has objectives to improve the welfare of people with and affected by leprosy, by running programs to improve in areas such as improvement of the social, economic and educational fields. Efforts to increase prosperity in these three areas using the value of Lifetime education such as trust (Trust), networks (networking), norms (norms). Independent Lepers Association organizes people affected by leprosy, which is the perception and the sense of shared destiny and same disability towards a decent living in the community to improve the welfare of the lepers. [6]. The lepers condition before the Association was formed was terrible. They had to look for drugs themselves, fought for their own health care, and became closed. However, 
after the Association was formed, they can be organized properly and became easier to get drugs, health services, and venture capital microeconomics.

Fostering trust is not easy to do, as well as the Independent Lepers Association. Many ways to do to build and maintain a trust, either individually or in groups. Lots of things to build trust among [7], by way of acceptance of self and others. Acceptance is done by growing mutual transparency to others.

Other efforts made by the Independent Lepers Association in building trust are by accepting, sharing information, forming a caring attitude among members, administrators, and community. [8], stated that the trust is a form of willingness to take risks in social relations were based on confident feeling that others will do something as expected and will always act in a pattern of mutual support. Trust a pillar of strength in Lifelong Education. Someone will be willing to do anything to others that he was confident that the person will take him to a better direction or in the direction he wanted. Obstacles encountered in building the trust that is the lack of openness among members of the management of so many programs or activities that are not going well. Hasbullah (2006) statement on trust is that people lose confidence and live in the spirit of inward-looking group that will encourage the flourishing of corruption, but the corruption of government and society will also promote the loss of social capital, things which affecting one another.

The Independent Leper Association maintained relation by offering a program of cooperation with various institutions, among them: Legal Aid assisted Parepare, Students of Law University, collaborates with NGOs Disabilities. It also cooperates with the mass Medias in order to hold the container dealer between the organization and society. In this network there are elements of the work concept, which through the medium of social relations into cooperation which is basically formed a social network for their mutual known and inform each other, remind each other and help each other in carrying out or solve anything. The concept of network in Life long education refers to all relationships with other people or groups that allow activities to run efficiently and effectively [9].

The trust and networks also created a norm within the community. The organization created a norm that which balance between the rights and obligations of members and officials of the Independent Lepers Association. Social norms have consequences, noncompliance with the norms or behaviors that are not in accordance with the norms in force causes a person get sanctions. Form of sanctions against the violation of norms may be an act (penalty) and could be a social sanctions more often shown in the form of attitudes, such as denial or does not involve a person who violates the norms, to engage in community activities. Obstacles faced by the organization is the lack of awareness and attitude of a member of the group which led to sanctions for those whose disobey it.

The Independent Lepers Association builds trust by transparency, maintain network and norms both internal and externally in order to gain the values of life long education and welfare of the lepers so that they can be accepted in the society, get proper living, well health care, and equal in social, political, and other life aspects.

\section{CONCLUSION}

Based on the analysis result of The Efforts of Independent Lepers Association in Developing Life Long Education among The Lepers in District of Soreang, Parepare, there were three points of conclusion: (1) The Independent Lepers Association builds people trust by developing transparency, forcing acceptance, growing caring and share information. Meanwhile, the obstacle faced is the lack of overtness among people within the community. (2) The Independent Lepers Association builds the relation by offering partnership to other institutions, spreading the brochures in order to inform other people about the existence of the organization. Meanwhile the obstacle faced is the low quality of human resources within the organization. (3) The Independent Lepers Association develops the norms by balancing between the rights and obligations of the welfare program in the community. Meanwhile, the obstacle faced is the lack of self-awareness and transparency one of organization member which affect other members to get sanction from disobeying the norms.

\section{REFERENCES}

[1] Effendi, Z. (Producer). (2011). 30 Percent Suffering Leperosy Dominat East Java Timor. Retrieved from

[2] RIDLEY, D. S. and JOPLING, W. H. Classification of leprosy according to immunity; a five-group system. Int. J. Lepr. 34 (1966) 255273

[3] IZUMI, S., SUGIYAMA, K., MATSUMOTO, Y. and OHKAWA, S. Analysis of the immunogenetic background of Japanese leprosy patients by the HLA system. Vox. Sang. 42 (1982) 243-247

[4] Harrison R, Reeve F, Hanson, A and Clarke J (2002) Supporting lifelong learning (Volume 1: Perspectives on learning) Milton Keynes: Open University Press. Crowther,

[5] Martin, I (2003) 'Adult education, lifelong learning and citizenship: some ifs and buts', International Journal of Lifelong Education, vol 22, (6) 566-579.

[6] J., Maclachlan, K. and Tett, L. (2010) 'Adult literacy, learning identities and pedagogic practice', International Journal of Lifelong Education, vol 29 (6) (Nov-Dec) 651-664.

[7] Yulia A.I. dan Budhy Santoso, Upaya Assocition Leprosy Approach Lifelong Education e-SOSPOL No. I Vol. 1; Januari 2014 [2014, I (1): 83-89] 86

[8] Hasbullah. (2009). Peran Lifelong Eduvation and Economy Market. 2006 Ichwani, C. H. (2012). 736 Case Study new Leprosy for doing this Parepare, solopos. Retrieved from

[9] Lawang, R. M. (2005a). Life Long Education the Perspektif Sisiology Suatu Pengantar. Jakarta FISIP UI Press. Association Leprosy. (2011). 